Abstract-The reproductive potential of northern rockfish (Sebastes polyspinis) and light dusky rockfish ( $S$. variabilis) in the Gulf of Alaska was examined by measuring the success of oocyte and embryo development. The potential annual fecundity, reproductive failure rates, and relationships of these parameters to maternal size were examined. Both species have a seasonally synchronous reproductive cycle with parturition occurring in the late spring to early summer. Northern rockfish had a mean relative fecundity of 165.1 oocytes/g for specimens captured in December and 109.6 embryos/g for specimens captured in May. Light dusky rockfish had a mean relative fecundity of 152.1 oocytes/g for specimens collected in December and 108.1 embryos/g for specimens captured in May. Reproductive failure was easiest to discern for the samples from fish collected in May, with partial and total failure primarily occurring because of lack of oocyte development or fertilization failure. Northern rockfish had a rate of total reproductive failure or skipped spawning of $16.3 \%$, and light dusky rockfish had a total reproductive failure rate of $15.6 \%$. As light dusky and northern rockfish grow larger throughout their lives, their relative fecundities increase and the likelihood of reproductive failure decreases. Fecundity values, failure rates, and maternal effects on the reproductive potential of these species can be used to inform future stock assessments.

Manuscript submitted 5 July 2018. Manuscript accepted 27 June 2019. Fish. Bull. 117:140-150 (2019). Online publication date: 12 July 2019. doi: 10.7755/FB.117.3.2

The views and opinions expressed or implied in this article are those of the author (or authors) and do not necessarily reflect the position of the National Marine Fisheries Service, NOAA.

\title{
Reproductive potential of light dusky rockfish (Sebastes variabilis) and northern rockfish (S. polyspinis) in the Gulf of Alaska
}

\author{
Christina L. Conrath \\ Email address for contact author: christina.conrath@noaa.gov \\ Kodiak Laboratory \\ Resource Assessment and Conservation Engineering Division \\ Alaska Fisheries Science Center \\ National Marine Fisheries Service, NOAA \\ 301 Research Court \\ Kodiak, Alaska 99615
}

The northern rockfish (Sebastes polyspinis) and light dusky rockfish (S. variabilis) are the second- and thirdmost commercially important rockfish species in Alaska waters, behind the Pacific ocean perch (S. alutus) (Hulson et al., 2015; Lunsford et al., 2016). Both species are captured predominately by bottom-trawl, catcher-processor fishing vessels or smaller shore-based trawlers operating out of Kodiak, Alaska (Clausen and Heifetz, 2002; Hulson et al., 2015). The stock assessments of these species in the Gulf of Alaska use a separable, age-structured model as the primary assessment tool. Input parameters to the model include fishery-dependent data, such as catch, age, size, composition, and maturity data, and fisheryindependent data, including estimates of biomass and age and size composition based on biennial trawl surveys (Hulson et al., 2015; Lunsford et al., 2016).

Northern rockfish range from waters of northern British Columbia and Alaska, across the North Pacific Ocean, to the eastern part of Kamchatka Peninsula and the northern Kuril Islands in Russia (Allen and Smith, 1988). They are most abundant in Alaska waters from the central Gulf of Alaska to the western Aleutian Islands. Adult northern rockfish in the Gulf of Alaska are found in relatively shallow offshore banks of the outer continental shelf at depths of $75-150 \mathrm{~m}$ They are the second-most abundant and commercially important rockfish in the Gulf of Alaska and the Aleutian Islands fisheries management areas (Clausen and Heifetz, 2002). Northern rockfish have supported a valuable domestic commercial fishery since 1990 in the Gulf of Alaska and were captured in foreign and joint venture fisheries prior to this period (Hulson et al., 2015).

Light dusky rockfish range from Hokkaido, Japan, through the Bering Sea and the Aleutian Islands, to Johnstone Strait, British Columbia (Love et al., 2002). Light dusky rockfish are commonly found at depths of $100-200 \mathrm{~m}$ in the Gulf of Alaska, and the highest catch per unit of effort generally occurs at depths of 100-149 m. Light dusky rockfish are most commonly associated with northern rockfish, Pacific ocean perch, and harlequin rockfish (S. variegatus), and bycatch of light dusky rockfish is highest in hauls of vessels targeting northern rockfish and vice versa (Reuter, 1999).

All species within the genus Sebastes mate using internal fertilization and give birth to planktonic larvae (Kendall and Lenarz, 1987). These species appear to be truly viviparous, meaning that the embryos receive sustenance from the mother in addition to yolk reserves during gestation (Boehlert et al., 1987). 
Maturity ogives have been published for both of these species (Chilton, 2007, 2010), but little information is available about other reproductive parameters. Maternal effects, abortive maturity, spawning omission or skipped spawning, and spatial disparities in the quantity of broods have all been documented for members of this genus (Hannah and Parker, 2007; Beyer et al., 2015; Conrath, 2017). Reproductive potential or the number of viable larvae released by a population at parturition is influenced by both the number of developing oocytes (potential fecundity) and the proportion of adults that have incomplete spawning (partial reproductive failure) or fail to spawn (total reproductive failure or skipped spawning). The objective of this project was to assess the reproductive potential of light dusky and northern rockfish at 2 different sites within the Gulf of Alaska by examining a variety of reproductive parameters, including development of oocytes and embryos within the ovary, gonadosomatic indices, potential annual fecundity, annual rates of reproductive failure, and maternal effects. Values for these parameters will be provided to stock assessment scientists for the management of these and other rockfish species in this region.

\section{Materials and methods}

Two research cruises were conducted in May (spring) and December (winter) 2014. During each cruise, 2 sites in the central Gulf of Alaska were sampled: one at 49 Fathom
Pinnacle and one on Snakehead Bank (Fig. 1). Both sites are located offshore of Kodiak Island near Middle and Southern Albatross Bank. We collected samples from female northern and light dusky rockfish at the site at 49 Fathom Pinnacle. Adult light dusky rockfish also were captured at the site at Snakehead Bank (Table 1). Each fish was measured for fork length (FL) and total weight, and the ovary was removed and preserved in a solution of $10 \%$ neutral buffered formalin.

A sample removed from the center of one lobe of the ovary from each specimen was embedded in paraffin and thin sectioned to $6 \mu \mathrm{m}$. Standard histological techniques were used to stain these tissue samples with hematoxylin and eosin (Sheehan and Hrapchak, 1980). These samples were used to examine the development of oocytes and embryos within the ovary, with stages defined on the basis of the terminology of Bowers (1992) (Table 2). Each sample was examined to determine which oocyte or embryo stages were present by using a compound microscope. The most advanced oocyte or embryo stage within the section was identified. In addition, the section was examined for the presence of atretic oocytes. Alpha atresia was characterized by the disintegration of the nucleus, irregularly shaped oocytes, disintegration of yolk, and the dissolution of the zona radiata. Beta atresia was characterized by oocytes having a compact structure composed of disorganized granulosa cells. Delta atresia was characterized by a dark yellow or brown pigment within the granulosa cells (Hunter and Macewicz, 1985a).

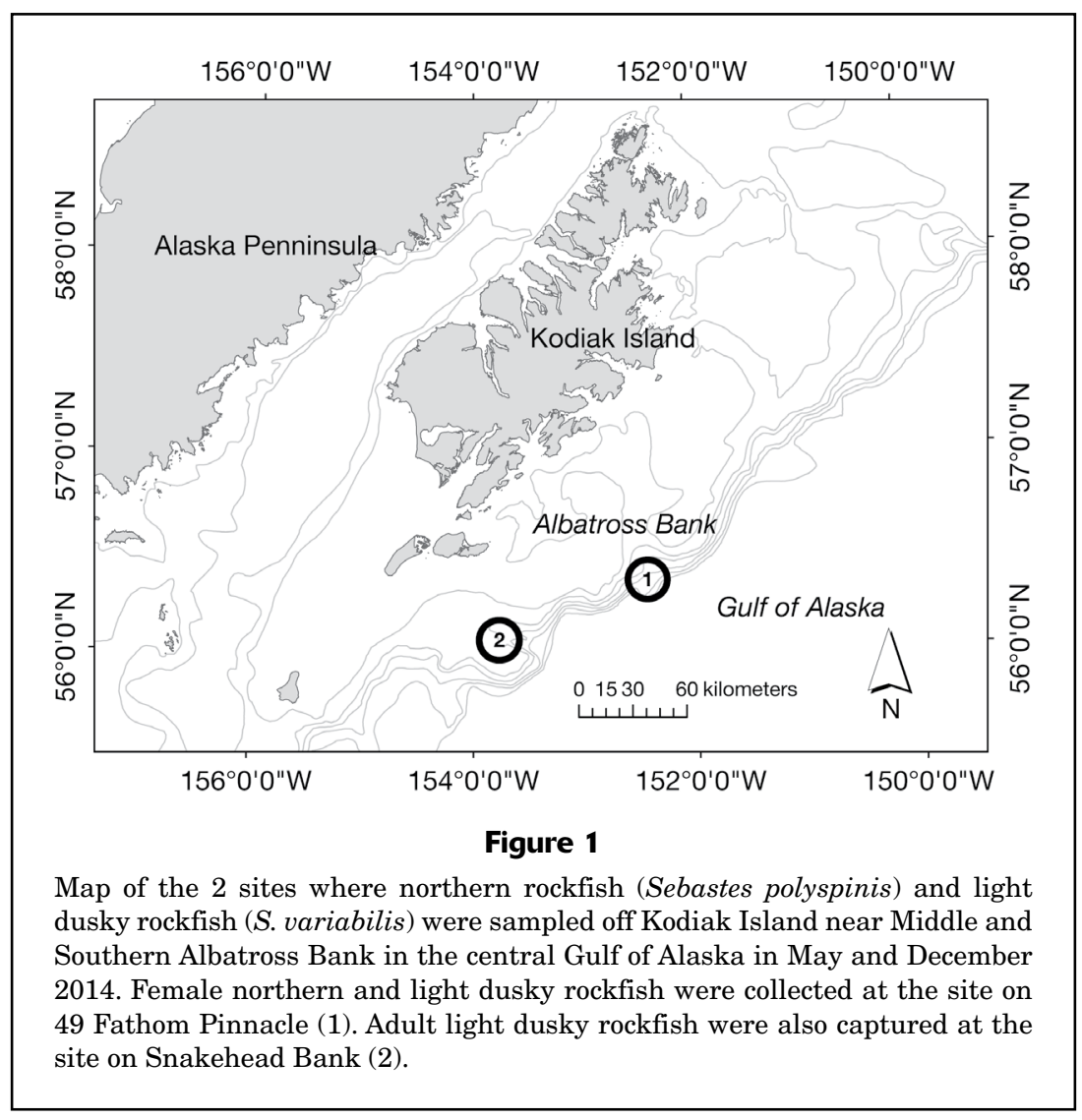




\section{Table 1}

Fork length (FL), total weight (TW), gonadosomatic index (GSI), potential annual fecundity (PAF), measured as the number of developing oocytes or embryos present within the female, and relative fecundity (RF), measured as PAF/TW, of female light dusky rockfish (Sebastes variabilis) and northern rockfish (S. polyspinis) collected during cruises conducted in the spring (May) and winter (December) of 2014 at 2 sites in the Gulf of Alaska: 49 Fathom Pinnacle (49 FP) and Snakehead Bank (SHB). The range, mean, standard error of the mean (SE), and sample size $(n)$ for each parameter are given.

\begin{tabular}{|c|c|c|c|c|c|c|c|}
\hline Species & Season & Site & $\mathrm{FL}(\mathrm{cm})$ & TW (g) & GSI & $\begin{array}{l}\text { PAF (no. of oocytes } \\
\text { or embryos) }\end{array}$ & $\begin{array}{l}\text { RF (oocytes/g } \\
\text { or embryos/g) }\end{array}$ \\
\hline \multirow[t]{4}{*}{$\begin{array}{l}\text { Light dusky } \\
\text { rockfish }\end{array}$} & \multirow[t]{2}{*}{ Spring } & $49 \mathrm{FP}$ & $\begin{array}{l}360-517 \\
\text { mean: } 456 \\
(n=100)\end{array}$ & $\begin{array}{l}720-2342 \\
\text { mean: } 1702 \\
(n=100)\end{array}$ & $\begin{array}{l}0.002-0.166 \\
\text { mean: } 0.088 \\
(\mathrm{SE} 0.007, n=60)\end{array}$ & $\begin{array}{l}31,510-330,700 \\
\text { mean: } 190,300 \\
(\mathrm{SE} 11,450, n=40)\end{array}$ & $\begin{array}{l}24.7-164 \\
\text { mean: } 106 \\
(\mathrm{SE} 5.46, n=40)\end{array}$ \\
\hline & & SHB & $\begin{array}{l}273-544 \\
\text { mean: } 465 \\
(n=105)\end{array}$ & $\begin{array}{l}260-3474 \\
\text { mean: } 1,963 \\
(n=105)\end{array}$ & $\begin{array}{l}0.001-0.197 \\
\text { mean: } 0.088 \\
(\mathrm{SE} 0.008, n=68)\end{array}$ & $\begin{array}{l}21,870-665,800 \\
\text { mean: } 256,200 \\
(\mathrm{SE} 23,690, n=36)\end{array}$ & $\begin{array}{l}\text { 18.3-216 } \\
\text { mean: } 111 \\
(\mathrm{SE} 6.97, n=36)\end{array}$ \\
\hline & \multirow[t]{2}{*}{ Winter } & $49 \mathrm{FP}$ & $\begin{array}{l}403-497 \\
\text { mean: } 457 \\
(n=138)\end{array}$ & $\begin{array}{l}1,066-2212 \\
\text { mean: } 1619 \\
(n=138)\end{array}$ & $\begin{array}{l}0.010-0.125 \\
\text { mean: } 0.041 \\
(\mathrm{SE} 0.001, n=89)\end{array}$ & $\begin{array}{l}49,290-455,100 \\
\text { mean: } 258,237 \\
(\mathrm{SE} 7635, n=103)\end{array}$ & $\begin{array}{l}46.2-273 \\
\text { mean: } 158 \\
(\mathrm{SE} 4.08, n=103)\end{array}$ \\
\hline & & SHB & $\begin{array}{l}332-525 \\
\text { mean: } 445 \\
(n=42)\end{array}$ & $\begin{array}{l}636-2418 \\
\text { mean: } 1494 \\
(n=42)\end{array}$ & $\begin{array}{l}0.004-0.043 \\
\text { mean: } 0.028 \\
(\mathrm{SE} 0.001, n=28)\end{array}$ & $\begin{array}{l}107,000-388,800 \\
\text { mean: } 227,600 \\
(\mathrm{SE} 14,4000, n=32)\end{array}$ & $\begin{array}{l}79.1-197 \\
\text { mean: } 140 \\
(\mathrm{SE} 5.14, n=32)\end{array}$ \\
\hline \multirow[t]{2}{*}{$\begin{array}{l}\text { Northern } \\
\text { rockfish }\end{array}$} & Spring & $49 \mathrm{FP}$ & $\begin{array}{l}345-453 \\
\text { mean: } 412 \\
(n=127)\end{array}$ & $\begin{array}{l}620-1466 \\
\text { mean: } 1162 \\
(n=127)\end{array}$ & $\begin{array}{l}0.070-0.222 \\
\text { mean: } 0.140 \\
(\text { SE } 0.006, n=38)\end{array}$ & $\begin{array}{l}62,650-212,000 \\
\text { mean: } 130,700 \\
(\mathrm{SE} 6118, n=36)\end{array}$ & $\begin{array}{l}53.2-176 \\
\text { mean: } 110 \\
(\mathrm{SE} 4.81, n=36)\end{array}$ \\
\hline & Winter & $49 \mathrm{FP}$ & $\begin{array}{l}270-463 \\
\text { mean: } 416 \\
(n=157)\end{array}$ & $\begin{array}{l}266-1738 \\
\text { mean: } 1183 \\
(n=157)\end{array}$ & $\begin{array}{l}0.013-0.091 \\
\text { mean: } 0.059 \\
(\mathrm{SE} 0.002, n=128)\end{array}$ & $\begin{array}{l}33,690-346,600 \\
\text { mean: } 197,100 \\
(\text { SE } 5347, n=121)\end{array}$ & $\begin{array}{l}43.9-251 \\
\text { mean: } 165 \\
(\mathrm{SE} 4.02, n=121)\end{array}$ \\
\hline
\end{tabular}

\section{Table 2}

Stages of oocyte and embryo development in ovaries of northern (Sebastes polyspinis) and light dusky (S. variabilis) rockfish. These stages, based on terminology of Bowers (1992), were used to identify the most advanced development stage present in samples from fish collected during May and December 2014 in the Gulf of Alaska.

Stage Physical description
1. Primary growth
2. Early yolk
3. Advanced yolk
4. Migratory nucleus
Oogonia, early perinuclear and late perinuclear ooyctes
Oocytes contain the earliest signs of yolk accumulation, small spherical globules of yolk in the periphery of the oocyte
Oocyte content is at least $50 \%$ yolk droplets, nucleus still well defined
Nucleus migrates to the periphery of the oocyte, nuclear membrane becomes irregular, nucleoli disappear
5. Ovulation
6. Early embryo
Yolk material begins to merge and form a single united mass
7. Embryo body
Blastoderm cap present with a large yolk mass
Embryo body appears, blastoderm cap of cells develops into recognizable tissue
8. Eyed embryo
Retinal pigmentation becomes apparent and is well defined
9. Embryo-reduced yolk
10. Postovulatory follicles
Yolk attached to the embryo is reduced in size and may only be present as droplets
The follicles that remain after parturition

Postovulatory follicles are the follicular structure that remains after the oocyte or larvae has been extruded (Hunter and Macewicz, 1985b).

Fish maturity status or class was determined by examining the most advanced oocyte stage present and the amount and types of atresia present. Fish were considered mature if there was evidence that they would spawn within the current reproductive year or evidence that they had spawned in a prior year. Immature fish included both those fish that had no oocyte development beyond stage 2 and those fish in which development had been resorbed (abortive mature). Mature fish included fish with incomplete or complete advanced oocyte development of stage 3 or higher and fish with no advanced development that were skipped spawners (Table 3). 


\section{Table 3}

Classifications used to determine maturity of northern rockfish (Sebastes polyspinis) and light dusky rockfish (S. variabilis) collected in May and December 2014 in the Gulf of Alaska. POF=postovulatory follicles. For stages of oocyte and embryo development, see Table 2.

\begin{tabular}{lll}
\hline Class & $\begin{array}{l}\text { Oocyte or embryo } \\
\text { development }\end{array}$ & Description \\
\hline Immature & $\begin{array}{l}\text { Primary growth } \\
\text { Abortive maturity }\end{array}$ & $\begin{array}{l}\text { No oocyte development beyond stage } 2 . \\
\text { Oocyte development is initiated, then oocytes are resorbed. No evidence of prior } \\
\text { spawning. Identified histologically by presence of widespread alpha atresia, but } \\
\text { no POFs or beta or delta atresia. }\end{array}$ \\
Oocyte or embryo development at stage 3 or at a more advanced stage of \\
development.
\end{tabular}

The ovary was patted dry at the laboratory, and a wet weight was recorded. A gonadosomatic index (GSI) was calculated for all mature fish by using the following equation: $G S I=$ gonad weight/total body weight. The mean and standard error of these values for each species during each season were determined. Ovary weights were unavailable for some fish whose ovary contained advanced embryos because the ovary structure was difficult to maintain. This delicate ovary structure was particularly prevalent in samples collected in May that contained eyed embryos with a thin and fragile ovarian wall that made it difficult to weigh the ovary without losing some of the embryos.

Fecundity was estimated at each site by using all individuals caught in December that had both lobes of their ovary and all specimens caught in May that had at least one complete lobe of their ovary. The difference between months sampled in which individuals were included was necessary because of the small number of individuals with a complete ovary that were collected in May. If only one lobe of the ovary was available, the total ovary weight was estimated by multiplying the weight of the complete lobe by 2 . Individual potential annual fecundity was estimated by using a gravimetric approach in which the weight of a subsample of oocytes or embryos present was extrapolated to estimate the total ovary weight. Fecundity was estimated by using only fish that had an ovary that was composed predominately of oocytes or embryos at a development stage of 3 or higher and that had no evidence of partial or total reproductive failure. In December, all ovaries examined contained oocytes that were in either the migratory nucleus or ovulation stages, whereas in May all ovaries contained eyed embryos. Therefore, values of fecundity for specimens captured in December are given in number of oocytes or number of oocytes per gram, and values of fecundity for specimens captured in May are given in either number of embryos or number of embryos per gram. Two subsamples were collected from randomly chosen quadrants of one lobe of the ovary. If the coefficient of variation from the 2 initial samples was greater than $5 \%, 2$ additional subsamples were collected. The individual potential annual fecundity was determined by averaging the fecundity estimates taken for each sample and multiplying by the total ovary weight. In addition, relative fecundity was determined by dividing potential annual fecundity by the total weight of the fish.

Reproductive failure in adult light dusky and northern rockfish was defined as partial or total lack of oocyte or embryo development in mature fish. Partial reproductive failure was identified by the presence of developing oocytes and non-developing oocytes within the ovary of a fish and was caused by incomplete fertilization (Fig. 2). Mature fish with no oocyte development were considered to be experiencing total reproductive failure and were classified as skipped spawners. Three types of skipped spawning similar to those defined by Rideout et al. (2005) were identified: resting skipped spawning (no initiation of oocyte development), resorbing skipped spawning 

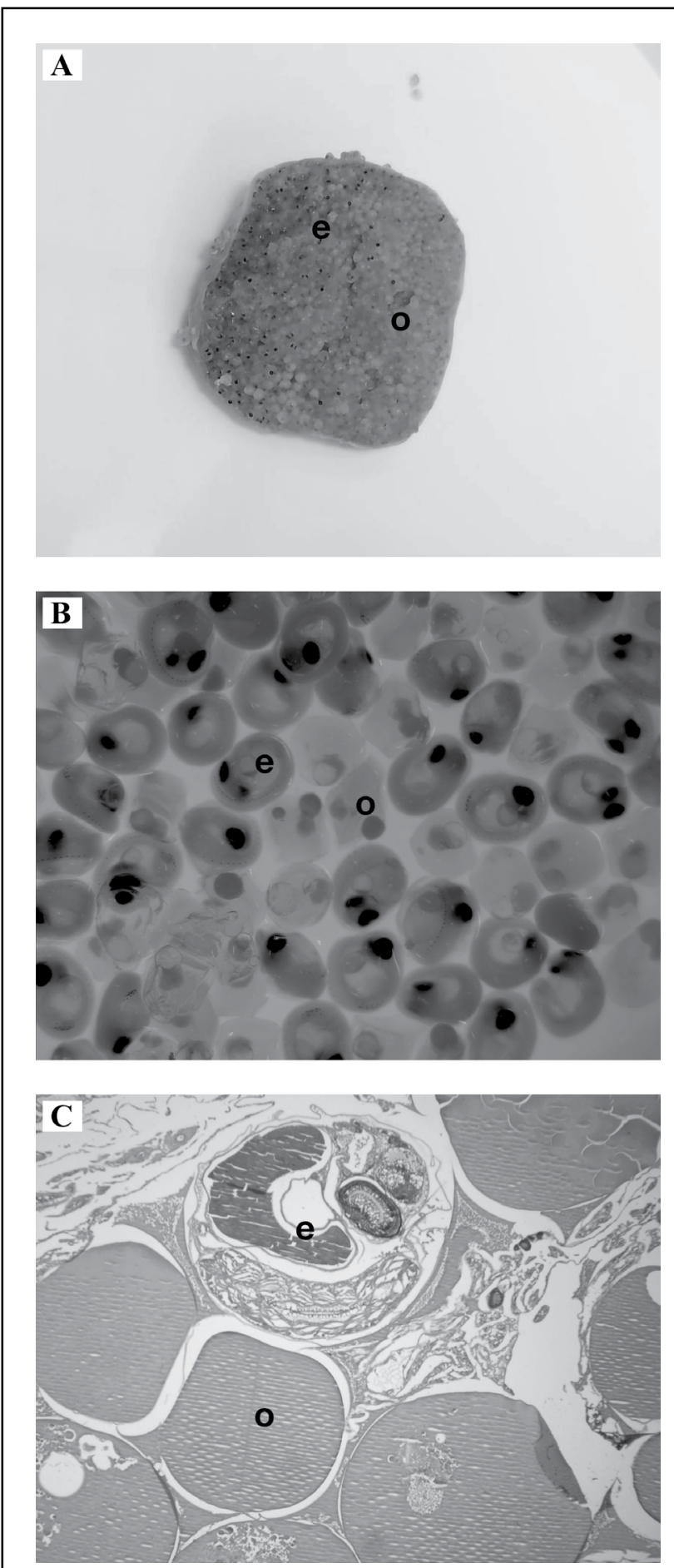

Figure 2

Images of ovary samples from northern rockfish (Sebastes polyspinis) collected in May 2014 in the Gulf of Alaska, showing partial reproductive failure due to incomplete fertilization. (A) A whole section of one lobe of an ovary. The left side of the lobe has fertilized embryos in the eyed stage (e), and the majority of the ovary is filled with unfertilized oocytes (o). (B) Several eyed embryos (e) and unfertilized oocytes (o) under a dissecting microscope. (C) A histological section with eyed embryos (e) and unfertilized oocytes (o). (oocytes that had initiated development were degenerating), and skipped spawning caused by fertilization failure (oocytes developed to the one-cell blastodisc stage but were not fertilized, and embryogenesis was not initiated) (Fig. 3). The proportion of adult northern and light dusky rockfish that had ovaries with partial or total reproductive failure were examined during the May and December sampling periods (Table 3).

Generalized linear models, with Gaussian distribution for response variables, were used to examine effects of maternal size, site, and season on relative fecundity.
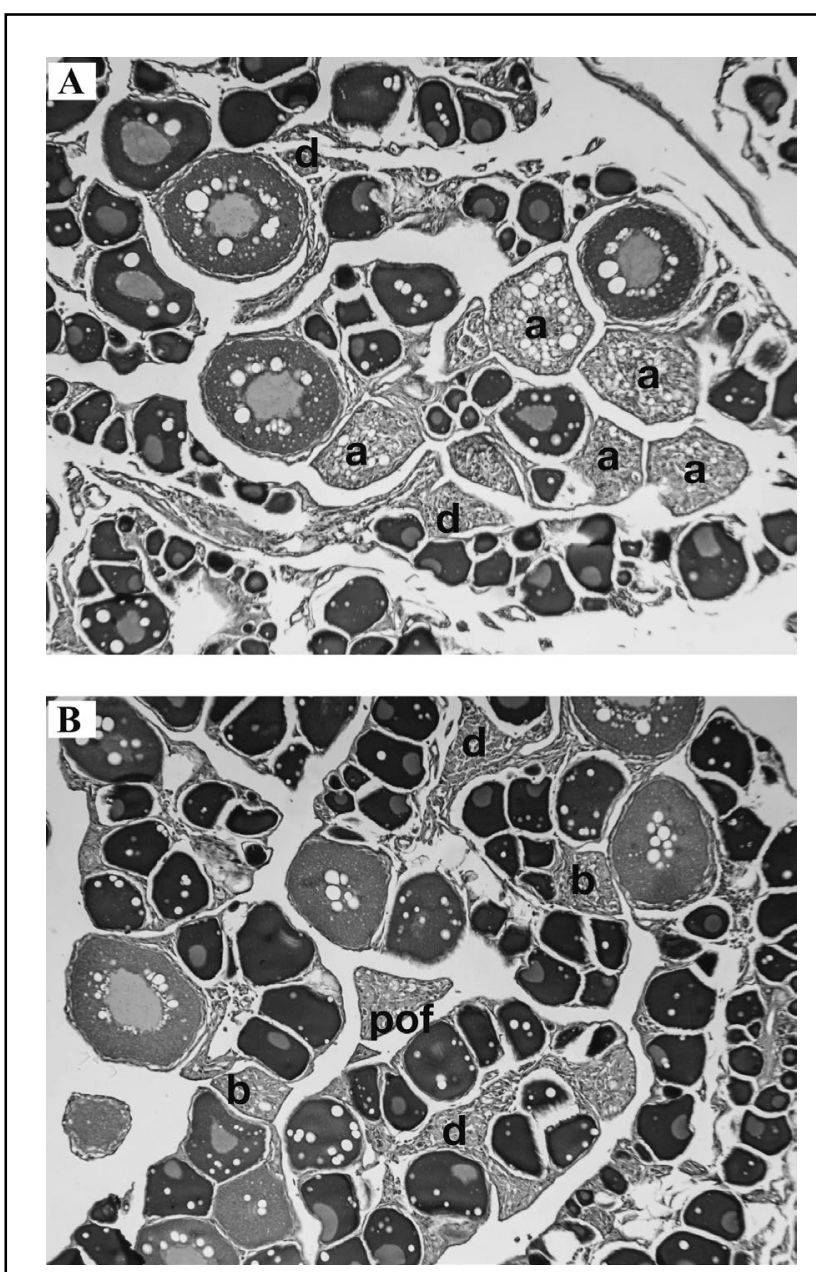

Figure 3

Images of sections of oocytes from northern rockfish (Sebastes polyspinis) captured in December 2014 in the Gulf of Alaska, showing 2 types of total reproductive failure or skipped spawning, with beta atresia (b), delta atresia (d), and potential postovulatory follicles (POF) that indicate a prior spawning. (A) Resorbing type of skipped spawning: section with alpha atresia (a) that indicates resorption of recently developing oocytes. (B) Resting type of skipped spawning: section with no alpha atresia or recent development present, a prior spawning is evident on the basis of late stage beta and delta atresia or the presence of post ovulatory follicles. 
Diagnostic plots of residual trends verses fitted values and standardized residuals versus theoretical quantiles (Q-Q plots) were examined visually for trends for each model. Generalized linear models with a binomial distribution were used to examine the effect of maternal size on reproductive failure. To test for overdispersion, each binomial model was repeated by using quasi-binomial distribution, and the dispersion parameter was examined. A backward stepwise approach was used to populate the models with explanatory parameters that were statistically significant $(\alpha=0.05)$. The GSI values were compared by site in each season. Effects of season, fish length, and site were considered in models fitted to relative fecundity data. Effects of fish length and site were considered in models fitted to values of fertilization failure and incomplete fertilization for fish captured in the month of May and to values of total reproductive failure for fish captured in May and December. Reproductive parameter values from the 2 sites sampled were combined if the site was not significantly related to the parameter being examined $(\alpha=0.05)$. The Akaike information criterion was used to determine which model best fit the data. The generalized linear models were completed by using the packages stats4 (vers. 3.2.0) and multcomp (vers. 3.2.5; Hothorn et al., 2008) in statistical software R, vers. 3.2.0 (R Core Team, 2015).

\section{Results}

Catches of northern and light dusky rockfish within both study sites were dominated by adult individuals with very few immature individuals and no individuals exhibiting abortive maturation. No adult northern rockfish were captured at the site on Snakehead Bank; therefore, comparisons between sites were limited to data for light dusky rockfish captured in both seasons. During May, all mature light dusky rockfish collected throughout both of the sampled sites that lacked evidence of reproductive failure had ovaries that were dominated by eyed embryos. This finding was also true for nearly all northern rockfish; one female contained embryos at the embryo body stage. During December, all mature individuals of both species had ovaries that were dominated by oocytes that were either in the late migratory nucleus or early ovulation stage unless there was evidence of reproductive failure. Both species were found to have highly synchronous oocyte and embryo development, and the timing of this development was very similar between the 2 species.

The GSI values for northern rockfish were generally higher than those for light dusky rockfish, and these values for both species were higher in May prior to parturition than in December (Table 1). The mean GSI for light dusky rockfish in May was not significantly related to site $(P=0.71)$. The mean GSI for light dusky rockfish captured in the month of December was considerably higher at 49 Fathom Pinnacle than at Snakehead Bank. There were no obvious trends in residuals in the model diagnostic plots for the GSI.
Estimates of fecundity were generally lower for northern rockfish than light dusky rockfish during both seasons, with higher values found during the winter (Table 1 ). Relative fecundity was calculated to compensate for the relationship between fecundity and size and was also greater for both species in December. Light dusky and northern rockfish had similar values of mean relative fecundity during each season. The mean relative fecundity of northern rockfish was 109.6 embryos/g for specimens captured in May and 165.1 oocytes/g for specimens captured in December. The mean relative fecundity of dusky rockfish was 108.1 embryos/g for fish captured in May and 152.1 oocytes/g for fish collected in December. Parameters tested in the model to explain variation in relative fecundity included site (for light dusky rockfish only), season, and FL (Table 4). Relative fecundity estimates were significantly higher $(P<0.001)$ in December than in May for both species and increased with size for both species (Fig. 4).

Total and partial reproductive failure occurred in both light dusky and northern rockfish and were found in both seasons. Reproductive failure was more prevalent and easier to discern in the specimens caught in May because of the advanced state of embryo development; therefore, only the data from the cruise conducted in May were used for this analysis. The proportion of adult individuals in which total reproductive failure had occurred was very similar for both species ( $16.3 \%$ for northern rockfish and $15.6 \%$ for light dusky rockfish), but the proportion of fish undergoing partial reproductive failure was higher in northern rockfish (14.9\%) than in light dusky rockfish $(3.7 \%)$. The most common type of total reproductive failure in northern rockfish, with $68.4 \%$ of cases, was the fertilization failure type of skipped spawning, and $31.6 \%$ of cases of total reproductive failure were due to the resting type of skipped spawning. For light dusky rockfish, more than half of total reproductive failure was due to the resting type of skipped spawning (55.2\%), a smaller proportion was due to the fertilization failure type of skipped spawning $(41.4 \%)$, and just one fish (3.4\%) was experiencing the resorbing type of skipped spawning. Rates of reproductive failure of light dusky rockfish were not significantly different between sites; therefore, failure rates for light dusky rockfish from both sites were combined in this analysis (total reproductive failure: $P=0.63$; fertilization failure and incomplete fertilization: $P=0.38$ ).

Larger fish of both species ( $>42 \mathrm{~cm} \mathrm{FL)} \mathrm{were} \mathrm{signifi-}$ cantly less likely to experience total reproductive failure, particularly failure due to resting skipped spawning (Fig. 5). The relationship of total reproductive failure caused by resting skipped spawning and FL was significant for both species (light dusky rockfish: $P=0.011$; northern rockfish: $P=0.044$ ), but the relationship between total reproductive failure caused by fertilization failure was significant only for northern rockfish (light dusky rockfish: $P=0.238$; northern rockfish: $P=0.002$ ). Partial or total reproduction failure due to incomplete fertilization or fertilization failure, however, was not significantly related to FL for either species (light dusky rockfish: 


\section{Table 4}

Results from use of generalized linear models to explain variation in relative fecundity of adult northern rockfish (Sebastes polyspinis) and light dusky rockfish (S. variabilis) captured in May and December 2014 in the Gulf of Alaska. Parameters include season, site (light dusky rockfish only), and fork length. Entries for the model that was determined to have the best fit to data for each species are italicized. Differences in Akaike information criterion ( $\triangle \mathrm{AIC}$ ) between the best fit model and the other models for each species are given.

\begin{tabular}{lclrr}
\hline Species & Model & Parameters & \multicolumn{1}{c}{$P$} & \multicolumn{2}{c}{$\Delta$ AIC } \\
\hline Northern rockfish & 1 & Season & $<0.001$ & \\
& & Fork length & 0.031 & \\
& 2 & Season & $<0.001$ & 2.8 \\
Light dusky rockfish & 3 & Fork length & 0.043 & 48.7 \\
& 1 & Season & $<0.001$ & 0.3 \\
& & Site & 0.206 & \\
& 2 & Fork length & $<0.001$ & \\
& & Fork length & $<0.001$ & \\
& 3 & Season & $<0.001$ & 29.5 \\
& & Season & $<0.001$ & \\
\end{tabular}
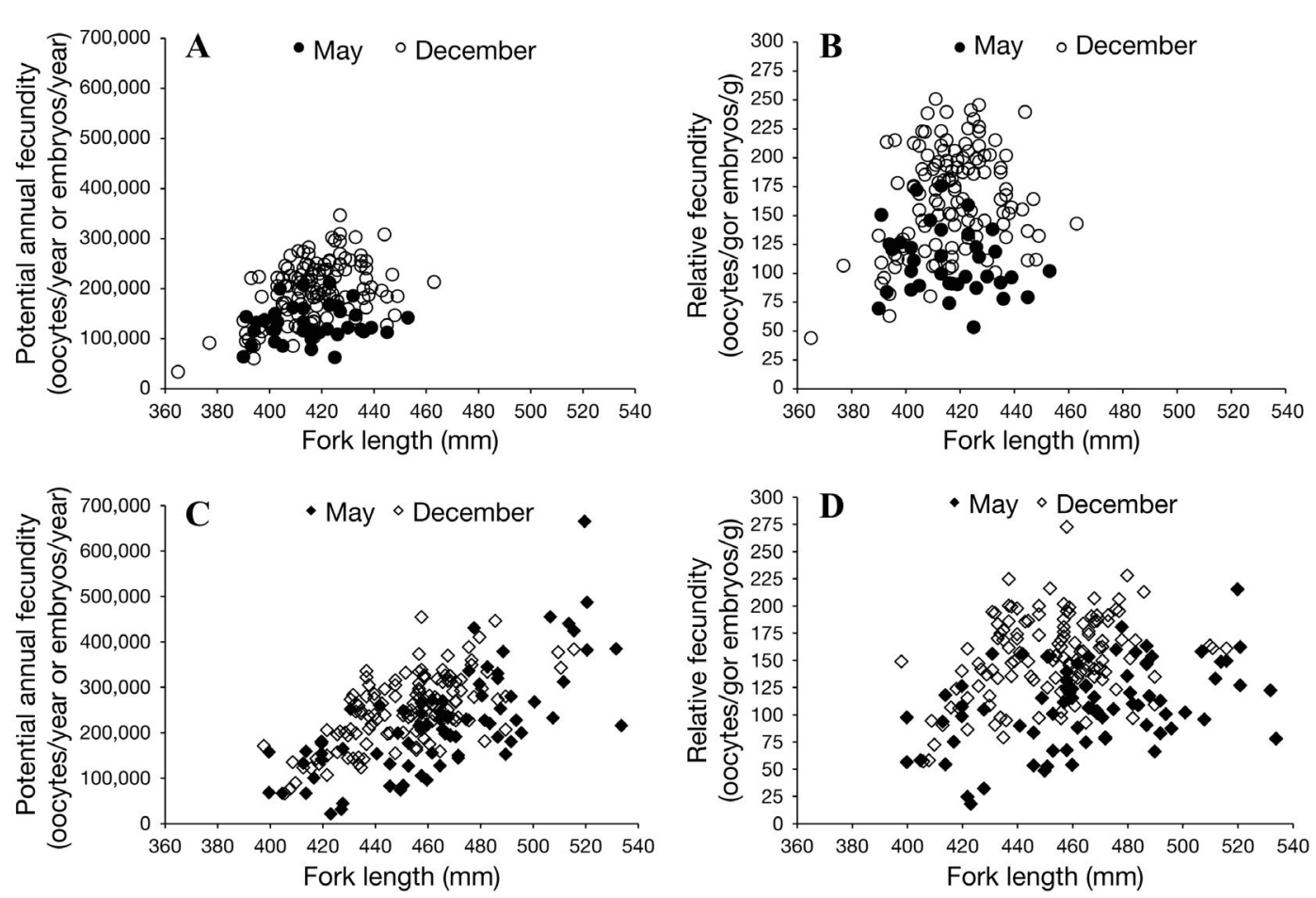

Figure 4

Relationships of potential annual fecundity, measured as number of developing oocytes or embryos, and of relative fecundity, calculated as potential annual fecundity divided by total weight, to fork length for (A and B) northern rockfish (Sebastes polyspinis) and (C and $\mathbf{D})$ light dusky rockfish (S. variabilis) collected during May and December 2014. Black circles and diamonds represent data for fish collected in May. Open circles and diamonds represent data for fish collected in December. 


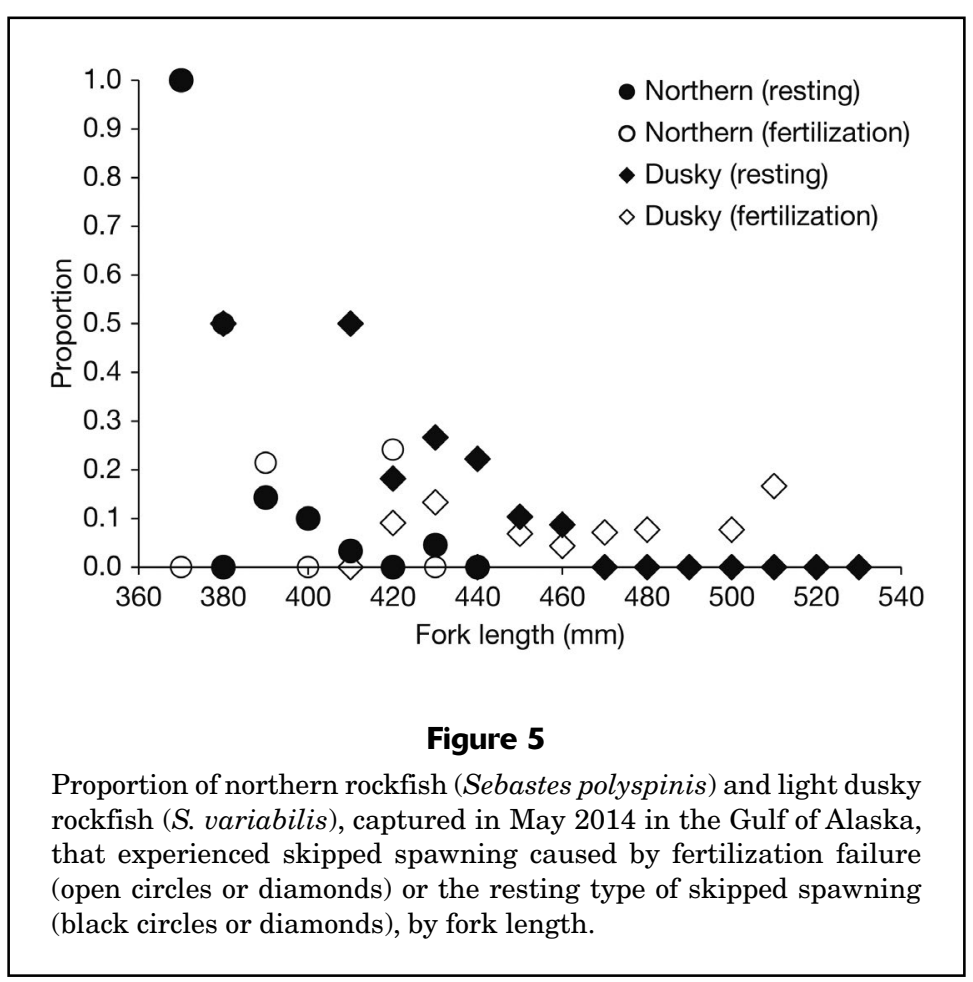

$P=0.278$; northern rockfish: $P=0.096)$. The quasi-binomial models all had dispersion values that were close to $1(<1.1)$, indicating that there was little overdispersion in all of these models.

\section{Discussion}

Light dusky and northern rockfish within the Gulf of Alaska have a highly synchronous reproductive cycle with nearly all individuals having ovaries dominated by oocytes or embryos in the same state of development in any period of the year. I calculated similar GSI values for both species during each of the 2 seasons. Although I sampled only during 2 periods of the year, results from this study are consistent with a synchronous annual cycle with parturition occurring in the early summer months. Fish of both species captured in December were in mid-vitellogenesis, and those captured in May were in late embryogenesis, indicating that they were nearing parturition. This timing is similar to that reported for northern rockfish in the Gulf of Alaska by Chilton (2007), who observed parturition occurring from April through June. Similarly, May has previously been reported as the peak month of parturition for light dusky rockfish in the Gulf of Alaska (Chilton, 2010). Northern rockfish in the Aleutian Islands appear to have a similar reproductive cycle, but the peak month of parturition is April (TenBrink and Spencer, 2013), indicating that reproductive events may occur earlier in the year in the region of the Aleutian Islands.

Fecundity estimates for both species were lower during the spring. Some loss of embryos occurred during capture in May because embryos are expelled as a result of the expansion of the swim bladder, potentially contributing to lower fecundity estimates during this period. However, it is also possible that some decrease in fecundity occurs during oocyte development. It is important to note that collections for this study occurred during 2 different reproductive cycles with the collections in May occurring in the reproductive year of 2014 and the collections in December occurring in the following reproductive year of 2015, and there may be interannual differences in fecundity due to environmental factors. It is assumed that the fecundity estimates for specimens collected in December may be more accurate because of the difficulty of collecting whole ovaries in May during the period of time close to parturition.

There are no published estimates of fecundity for either of these species in the Gulf of Alaska, but fecundity of northern rockfish has been examined in the Aleutian Islands. TenBrink and Spencer (2013) found that average fecundity of this species was 89,320 oocytes for northern rockfish ranging in size from 28 to $43 \mathrm{~cm} \mathrm{FL}$. They found that individuals of this species produce more oocytes than is explained by a proportional relationship between fecundity and maternal weight. The large disparity between the mean fecundity reported by TenBrink and Spencer (2013) and the mean fecundity calculated in this study is likely due to the larger sizes of fish examined in our study (37-46 cm FL). For most Sebastes species, there is a relationship between fecundity and size of fish, and for many of these species relative fecundity increases with the size of fish (Boehlert at al., 1982; Bobko and Berkeley, 2004; Dick, 2009).

It is important to distinguish reproductive failure from abortive maturation. Abortive maturation occurs when 
immature fish that have not previously reproduced initiate oocyte development through vitellogenesis but have this process interrupted and their developing oocytes reabsorbed (Hannah and Parker, 2007; Conrath and Knoth, 2013). This phenomenon is commonly found in species that are members of the genus Sebastes (Nichol and Pikitch, 1994). It can be distinguished histologically because immature individuals will have no evidence of a prior spawning (beta and delta atresia or postovulatory follicles). In contrast to work that has examined abortive maturity that occurs in immature individuals, analysis of reproductive failure in this study included only those individuals that had reproduced in a prior year and were classified as mature adults. Almost all the individuals captured for this study were adults, and the average size of fish captured for this study (light dusky rockfish: $458 \mathrm{~mm}$ FL; northern rockfish: $414 \mathrm{~mm} \mathrm{FL}$ ) was quite a bit larger than the previously reported size at 50\% maturity of either species, $310 \mathrm{~mm}$ FL for northern rockfish and 365 mm FL for light dusky rockfish (Chilton, 2007, 2010). This difference in size and maturity is likely the reason that no individuals undergoing abortive maturation were collected during this study.

Skipped spawning may ensure that fish of these species spawn only in years when adequate energy is available to produce viable embryos or to optimize their lifetime reproductive output. This pattern may be particularly important for rockfish species in Alaska that are long lived and have a periodic life history strategy (Winemiller and Rose, 1992). Skipped spawning may occur when fish experience decreased food availability (Rideout and Rose, 2006; McBride et al., 2015) and may be related to condition and energy reserves (Skjæraasen et al., 2012; Skjæraasen et al., 2015). If skipped spawning is related to energy reserves, it will likely vary temporally and the proportion of skipped spawners will fluctuate with changing environmental conditions. Interannual variability in the amount of skipped spawning has been documented for several teleost species, including haddock (Melanogrammus aeglefinus) in the northeast Arctic Ocean (Skjæraasen et al., 2015), Atlantic cod (Gadus morhua) off Newfoundland and Labrador, Canada (Rideout et al., 2006), and spring-spawning Atlantic herring (Clupea harengus) off Norway (Engelhard and Heino, 2006). It is important to consider not only annual changes in the amount of skipped spawning but spatial differences in rates of skipped spawning across the geographic range of a species.

The lack of fertilization type of skipped spawning has not been documented in rockfish species in this region prior to this study. This type of skipped spawning is similar to the retained type of skipped spawning described in Rideout et al. (2005) but differs for the live bearing species of the genus Sebastes because it is caused by lack of fertilization. In northern rockfish, there is some evidence from this study that the fertilization failure type of skipped spawning occurred more frequently in smaller fish $(<42 \mathrm{~cm} \mathrm{FL})$; this relationship was not apparent in light dusky rockfish. Additional studies examining how incomplete fertilization or fertilization failure may relate to sex ratios, mate availability, mating behavior and competition, and female size and experience are needed.
However, it is suspected that the lack of fertilization success observed in this study may be due to a large copepod parasite (Sarcotaces sp.) that can be found within the body cavity of rockfish species. This parasite is found encysted in the skin and muscle tissue of marine fish, particularly in members of the genus Sebastes in the North Pacific Ocean (Meyers et al. ${ }^{1}$ ). In some species, this parasite may form a physical blockage in the body cavity or the reproductive tract and create problems with fertilization and spawning events. This parasite appears to occur frequently in dusky rockfish (Sebastes ciliatus) (Worton ${ }^{2}$ ), and this parasite is frequently seen in both light dusky and northern rockfish. The presence and number of this parasite were not consistently recorded in this study; therefore, calculating a correlation value between this parasitism and lack of fertilization was not possible. Further study is needed to examine the correlation between reproductive failure and the presence of this parasite.

Reproductive failure of northern and light dusky rockfish has not been documented in prior studies that examined the reproductive parameters of these species in the Gulf of Alaska (Chilton, 2007, 2010). TenBrink and Spencer (2013) in a study of the reproductive biology of Pacific ocean perch and northern rockfish mentioned that a small number of specimens may have been skipped spawners on the basis of the presence of postovulatory follicles and atretic oocytes, but skipped spawning apparently was not common. Specimens for this project were collected in 2014, when there was a warmwater anomaly in the Gulf of Alaska. This mass of warm water developed in the northeast Pacific Ocean during the winter of 2013-2014, and anomalies of warm sea-surface temperatures reached coastal waters of Alaska in May 2014 (Bond et al., 2015). This area of warm water was present through the end of 2015 and had widespread impacts on the oceanic and coastal ecosystems of the northeast Pacific Ocean (Cavole et al., 2016). It is possible that the 2 reproductive years covered by my study were impacted by this warmwater mass or other environmental conditions specific to this time period, and additional study of these processes during a more comprehensive time span is needed.

The greater contribution larger females make to several aspects of reproductive potential has been documented for members of the genus Sebastes; these aspects include increased fecundity (Beyer et al., 2015), increased larval quality (Berkeley et al., 2004), and earlier spawning, more protracted spawning, or both (Sogard et al., 2008). The results of this study indicate that larger females have higher relative fecundity and are less likely to experience total reproductive failure. The pattern of decreasing reproductive failure appears to be driven by a decrease in

\footnotetext{
${ }^{1}$ Meyers, T., T. Burton, C. Bentz, J. Ferguson, D. Stewart, and N. Starkey. 2019. Diseases of wild and cultured fishes in Alaska, 128 p. Alaska Dep. Fish Game, Anchorage, AK. [Available from website.]

${ }^{2}$ Worton, C. 2018. Personal commun. Alaska Department of Fish and Game, 351 Research Ct., Kodiak, AK 99615.
} 
skipped spawning with size or age. This pattern has also been documented for deepwater rockfish species in the Gulf of Alaska (Conrath, 2017). A relationship between incomplete fertilization or fertilization failure and size was not observed in this study.

Reproductive failure has the potential to affect recruitment to the fishery of these 2 species in the Gulf of Alaska; therefore, it is critical to understand how this aspect of the life history of northern and light dusky rockfish should inform the management of these species. Research results indicate that spawning stock biomass or estimates of oocyte production per recruit can be inflated when adult fish that are not spawning are included as a part of the spawning stock (Rideout et al., 2005; Rideout and Rose, 2006; Sitar et al., 2014). Skipped spawning likely varies with metabolic condition, reflecting environmental parameters. Therefore, the proportion of a population of northern rockfish or light dusky rockfish that is not spawning likely varies annually, and there may be other temporal patterns in reproductive success related to changes in abundance of parasites, prey, and predators and in environmental parameters. Time-series data on reproductive parameters and specifically on rates of skipped spawning are needed to understand the implications for fish populations and their management (Rideout and Tomkeiwicz, 2011).

\section{Acknowledgments}

I thank B. Knoth, C. Rooper, D. Benjamin, M. Yang, and A. Vijgen for invaluable field and laboratory assistance. I am grateful to the captains and crew of the commercial fishing vessels chartered to participate in this research, the F/V Gold Rush and the F/V Pacific Storm, including B. Ashley, D. Ashely, and S. Hockema. I thank my funding sources: the North Pacific Research Board, the Alaska Coral and Sponge Initiative of the National Marine Fisheries Service, and the Habitat and Ecological Processes Research Program of the NOAA Alaska Fisheries Science Center.

\section{Literature cited}

Allen, M. J., and G. B. Smith.

1988. Atlas and zoogeography of common fishes in the Bering Sea and northeastern Pacific. NOAA Tech. Rep. NMFS 66, $151 \mathrm{p}$.

Berkeley, S. A., C. Chapman, and S. M. Sogard.

2004. Maternal age as a determinant of larval growth and survival in a marine fish, Sebastes melanops. Ecology 85:1258-1264. Crossref

Beyer, S. G., S. M. Sogard, C. J. Harvey, and J. C. Field.

2015. Variability in rockfish (Sebastes spp.) fecundity: species contrasts, maternal size effects, and spatial differences. Environ. Biol. Fish. 98:81-100. Crossref

Bobko, S. J., and S. A. Berkeley.

2004. Maturity, ovarian cycle, fecundity, and age-specific parturition of black rockfish (Sebastes melanops). Fish. Bull. 102:418-429.
Boehlert, G. W., W. H. Barss, and P. B. Lamberson.

1982. Fecundity of the widow rockfish, Sebastes entomelas, off the coast of Oregon. Fish. Bull. 80:881-884.

Boehlert, G. W., M. Kusakari, and J. Yamada.

1987. Reproductive mode and energy costs of reproduction in the genus Sebastes. In Proceedings of the international rockfish symposium; Anchorage, AK, 20-22 October 1986, p. 143-152. Alaska Sea Grant Rep. 87-02. Alaska Sea Grant Coll. Program, Univ. Alaska Fairbanks, Fairbanks, AK.

Bond, N. A., M. F. Cronin, H. Freeland, and N. Mantua.

2015. Causes and impacts of the 2014 warm anomaly in the NE Pacific. Geophys. Res. Lett. 42:3414-3420. Crossref

Bowers, M. J.

1992. Annual reproductive cycle of oocytes and embryos of yellowtail rockfish Sebastes flavidus (Family Scorpaenidae). Fish. Bull. 90:231-242.

Cavole, L. M., A. M. Demko, R. E. Diner, A. Giddings, I. Koester, C. M. L. S. Pagniello, M.-L. Paulsen, A. Ramirez-Valdez, S. M. Schwenck, N. K. Yen, et al.

2016. Biological impacts of the 2013-2015 warm-water anomaly in the Northeast Pacific: winners, losers, and the future. Oceanography 29:273-285. Crossref

Chilton, E. A.

2007. Maturity of female northern rockfish Sebastes polyspinis in the central Gulf of Alaska. Alaska Fish. Res. Bull. 12:264-269.

2010. Maturity and growth of female dusky rockfish (Sebastes variabilis) in the central Gulf of Alaska. Fish. Bull. 108:70-78.

Clausen, D. M., and J. Heifetz.

2002. The northern rockfish, Sebastes polyspinis, in Alaska: commercial fishery, distribution, and biology. Mar. Fish. Rev. 64(4):1-28.

Conrath, C. L.

2017. Maturity, spawning omission, and reproductive complexity of deepwater rockfish. Trans. Am. Fish. Soc. 146:495-507. Crossref

Conrath, C. L., and B. Knoth.

2013. Reproductive biology of Pacific ocean perch in the Gulf of Alaska. Mar. Coast. Fish. 5:21-27. Crossref

Dick, E. J.

2009. Modeling the reproductive potential of rockfishes (Sebastes spp.). Ph.D. diss., 229 p. Univ. Calif. Santa Cruz, CA.

Engelhard, G. H., and M. Heino.

2006. Climate change and condition of herring (Clupea harengus) explain long-term trends in extent of skipped reproduction. Oecologia 149:593-603. Crossref

Hannah, R. W., and S. J. Parker.

2007. Age-modulated variation in reproductive development of female Pacific ocean perch (Sebastes alutus) in waters off Oregon. In Biology, assessment, and management of North Pacific rockfishes. Alaska Sea Grant Rep. 07-01 (J. Heifetz, J. DiCosimo, A. J. Gharrett, M. S. Love, V. M. O'Connell, and R. D. Stanley, eds.), p. 161-180. Alaska Sea Grant Coll. Program, Univ. Alaska Fairbanks, Fairbanks, AK.

Hothorn, T., F. Bretz, and P. Westfall.

2008. Simultaneous inference in general parametric models. Biom. J. 50:346-363. Crossref

Hulson, P.-J. F., J. Heifetz, D. H. Hanselman, S. K. Shotwell, and J. N. Ianelli.

2015. Assessment of the northern rockfish stock in the Gulf of Alaska. In Stock assessment and fishery evaluation report for the groundfish resources of the Gulf of Alaska, p. 889974. North Pacific Fish. Manage. Counc., Anchorage, AK. [Available from website.] 
Hunter, J. R., and B. J. Macewicz.

1985a. Rates of atresia in the ovary of captive and wild northern anchovy, Engraulis mordax. Fish. Bull. 83:119-136.

1985b. Measurement of spawning frequency in multiple spawning fishes. In An egg production method for estimating spawning biomass of pelagic fish: application to the northern anchovy, Engraulis mordax (R. Lasker, ed.), p. 79-94. NOAA Tech. Rep. NMFS 36.

Kendall, A. W., Jr., and W. H. Lenarz.

1987. Status of early life history studies of northeast Pacific rockfishes. In Proceedings of the international rockfish symposium; Anchorage, 20-22 October 1986, p. 99-128. Alaska Sea Grant Rep. 87-02. Alaska Sea Grant Coll. Program, Univ. Alaska Fairbanks, Fairbanks, AK.

Love, M. S., M. Yoklavich, and L. Thorsteinson.

2002. The rockfishes of the northeast Pacific, 405 p. Univ. Calif. Press, Berkeley, CA.

Lunsford, C. R., S. K. Shotwell, P.-J. F. Hulson, and D. H. Hanselman.

2016. Assessment of the dusky rockfish stock in the Gulf of Alaska. In Stock assessment and fishery evaluation report for the groundfish resources of the Gulf of Alaska. North Pacific Fish. Manage. Counc., Anchorage, AK. [Available from website.]

McBride, R. S., S. Somarakis, G. R. Fitzhugh, A. Albert, N. A. Yaragina, M. J. Wuenschel, A. Alonso-Fernández, and G. Basilone.

2015. Energy acquisition and allocation to egg production in relation to fish reproductive strategies. Fish Fish. 16:23-57. Crossref

Nichol, D. G., and E. K. Pikitch.

1994. Reproduction of darkblotched rockfish off the Oregon coast. Trans. Am. Fish. Soc. 123:469-481. Crossref

$\mathrm{R}$ Core Team.

2015. R: a language and environment for statistical computing. R Foundation for Statistical Computing, Vienna, Austria. [Available from website, accessed April 2015.]

Reuter, R.F.

1999. Describing dusky rockfish (Sebastes ciliatus) habitat in the Gulf of Alaska using historical data. M.S. thesis, 83 p. Calif. State Univ., Hayward, CA.

Rideout, R. M., and G. A. Rose.

2006. Suppression of reproduction in Atlantic cod Gadus morhua. Mar. Ecol. Prog. Ser. 320:267-277. Crossref
Rideout, R. M., and J. Tomkiewicz.

2011. Skipped spawning in fishes: more common than you might think. Mar. Coast. Fish. 3:176-189. Crossref

Rideout, R. M., G. A. Rose, and M. P. M. Burton.

2005. Skipped spawning in female iteroparous fishes. Fish Fish. 6:50-72. Crossref

Rideout, R. M., M. J. Morgan, and G. R. Lilly.

2006. Variation in the frequency of skipped spawning in Atlantic cod (Gadus morhua) off Newfoundland and Labrador. ICES J. Mar. Sci. 63:1101-1110. Crossref

Sheehan, D. C., and B. B. Hrapchak.

1980. Theory and practice of histotechnology, 2nd ed., $481 \mathrm{p}$. Battelle Press, Columbus, $\mathrm{OH}$.

Sitar, S. P., A. J. Jasonowicz, C. A. Murphy, and F. W. Goetz.

2014. Estimates of skipped spawning in lean and siscowet lake trout in southern Lake Superior: implications for stock assessment. Trans. Am. Fish. Soc. 143:660-672. Crossref

Skjæraasen, J. E., R. D. M. Nash, K. Korsbrekke, M. Fonn, T. Nilsen, J. Kennedy, K. H. Nedreaas, A. Thorsen, P. R. Witthames, A. J. Geffen, et al.

2012. Frequent skipped spawning in the world's largest cod population. Proc. Natl. Acad. Sci. U.S.A. 109:8995-8999. Crossref

Skjæraasen, J. E., K. Korsbrekke, T. Nilsen, M. Fonn, O. S. Kjesbu, G. E. Dings $\varnothing$, and R. D. M. Nash.

2015. Skipped spawning in Northeast Arctic haddock Melanogrammus aeglefinus. Mar. Ecol. Prog. Ser. 526:143-155. Crossref

Sogard, S. M., S. A. Berkeley, and R. Fisher.

2008. Maternal effects in rockfishes Sebastes spp.: a comparison among species. Mar. Ecol. Prog. Ser. 360:227-236. Crossref

TenBrink, T. T., and P. D. Spencer.

2013. Reproductive biology of Pacific ocean perch and northern rockfish in the Aleutian Islands. North Am. J. Fish. Manage. 33:373-383. Crossref

Winemiller, K. O., and K. A. Rose.

1992. Patterns of life-history diversification in North American fishes: implications for population regulation. Can. J. Fish. Aquat. Sci. 49:2196-2218. Crossref 